\title{
The Effect of Debt Policies, Profitability, Managerial Ownership Structure, and Liquidity on Dividend Policy
}

\author{
ZAINUDDIN* \\ OKFITA ANDARESTA MANAHONAS
}

Universitas Khairun

\begin{abstract}
This study aims to determine the effect of debt policy, profitability, managerial ownership, and liquidity on dividend policy on manufacturing companies listed on the Indonesia Stock Exchange in 2014-2018. The sample in this study was manufacturing companies listed on the Indonesia Stock Exchange in 2014-2018. This study's sampling technique was purposive sampling, which took samples based on specific predetermined criteria. The number of samples in this study amounted to 60 observations. The data analysis technique used is multiple linear regression analysis techniques. The results of this study indicate that 1). Debt policy does not affect on dividend policy; 2). Profitability has a positive effect on dividend policy; 3) Managerial ownership does not affect on dividend policy, and 4) Liquidity does not affect dividend policy.
\end{abstract}

Keywords: Debt policy, profitability, managerial ownership, liquidity, and dividend policy

Abstrak: Penelitian ini bertujuan untuk mengetahui pengaruh kebijakan hutang, profitabilitas, kepemilikan manajerial dan likuiditas terhadap kebijakan dividen pada perusahaan manufaktur yang terdaftar di Bursa Efek Indonesia pada tahun 2014-2018. Sampel dalam penelitian ini adalah perusahaan manufaktur yang terdaftar di Bursa Efek Indonesia pada tahun 2014-2018. Teknik pengambilan sampel yang digunakan dalam penelitian ini adalah purposive sampling yaitu proses pengambilan sampel berdasarkan kriteria tertentu yang telah ditetapkan. Jumlah sampel dalam penelitian ini berjumlah 60 observasi. Teknik analisis data yang digunakan yaitu teknik analisis regresi linier berganda. Hasil penelitian ini menunjukkan bahwa 1). Kebijakan hutang tidak berpengaruh terhadap kebijakan dividen; 2). Profitabilitas berpengaruh positif terhadap kebijakan dividen; 3) Kepemilikan manajerial tidak berpengaruh terhadap kebijakan dividen; dan 4) Likuiditas tidak berpengaruh terhadap kebijakan dividen.

Kata Kunci: Kebijakan hutang, profitabilitas, kepemilikan manajerial, kebijakan likuiditas dan dividen. 


\section{Introduction}

The capital market is the same as the market in general, a meeting place between sellers and buyers with the risk of profit and loss. The capital market is a company that means to increase long-term funding needs by selling shares. The capital market is a means of funding for companies and other institutions (for example, the government), and as a means for investing activities. Investment is the placement of several funds at this time to expect returns that will occur in the future (Clarensia et al., 2017).

One of the attractions in investing is dividends. A dividend is a distribution of profit paid to shareholders based on the number of shares owned (Siegel and Shim, 1999). The more company shares owned by investors, the higher the shareholders' dividends will receive in each period. Hartono (2000) also states that management often uses dividends to signal the company's prospects. Furthermore, Hatta (2002) states that dividend policy is often seen as a signal for investors in assessing a company's merits.

Investors as shareholders have the right to elect the company's board of commissioners. Meanwhile, the board of commissioners will appoint a manager to carry out the company's operational activities. Therefore, there will be a separation between ownership and management. They will make decisions according to their respective positions and interests, which will lead to an agency relationship. Agency problems can occur because of the asymmetry of information between the principal and the agent. The emergence of information asymmetry and a conflict of interest between the two is considered an essential source of inefficiency in the decision-making process (Miguel et al., 2005). In this regard, the financial literature broadly supports the role of ownership, debt, and dividend structures as agency cost control mechanisms. First, the financial literature states the benefits of managerial ownership (Jensen and Meckling, 1976; Shleifer and Vishny, 1986), debt (Jensen, 1986), and dividends (Rozeff 1982) in resolving conflicts of interest that arise between shareholders and managers in the company. Second, it is found that ownership structures, debt (Harris and Raviv, 1990), and dividends (Bhattacharya, 1979) are effective ways to reduce information asymmetry between firms and investors. 
According to Rachmawati (2016), the right debt policy will increase dividend distribution. If the use of debt is too high, it will decrease dividends, where most of the profits will be allocated as reserves for debt settlement. On the other hand, at a low level of debt, the company will distribute high dividends so that most of the profits are used for shareholders' welfare (Rachmawati, 2016). Research conducted by Bansaleng (2014) and Thaib (2015) proves that debt policy affects dividend policy, while research by Affifah (2018) and Rachmawati (2016) proves that debt policy does not affect dividend policy.

The company's ability to earn profits is the primary indicator of its ability to pay dividends (Wijayanti, 2016). Profitability is the main factor for companies in distributing dividends to shareholders, so that profitability is the most crucial final factor for dividend policy. The greater the profit available to shareholders, the greater the dividend payment to shareholders or the allocation for retained earnings (Rais and Santoso, 2017). Research conducted by Bansaleng (2014), Thaib (2015), and Yudiana (2016) prove that profitability affects dividend policy, while research according to Bawamenewi (2019) and Rais (2017) proves that profitability does not affect dividend policy.

The managerial ownership structure is also one that influences dividend policy. Managerial ownership is ownership where there is involvement between shareholders, namely commissioners and directors, who play an active role in decision making to get equality with other shareholders (Rais and Santoso, 2017). Singh and Davidson III (2003) stated that large companies' manager ownership could significantly reduce conflicts between principals and agents. The greater the involvement of managers in managerial ownership in managerial ownership causes the assets owned not to diversify optimally so that they want more significant dividends. Families own most of the shareholding structures of companies in Indonesia, so they tend to pay high dividends. Manager behavior leads to relatively high dividends as a return on share ownership (Nuringsih, 2005). Research conducted by Isticharoh (2016), Affifah (2018), Sindhu, et al. (2016), and Indriani (2016) proves that managerial ownership structure affects 
dividend policy while Bansaleng (2014) and Rais (2017) research proves that the Managerial structure ownership does not affect dividend policy.

Another factor that influences dividend policy is the liquidity ratio. According to Monika (2018), liquidity is a ratio that describes a company's ability to pay the shortterm debt. Research conducted by Nurchaqiqi and Trisni (2018), Jiang, et al. (2016), and Hashim (2017) prove that liquidity affects dividend policy, while the research of Andriyani (2017) and Yudistra et al. (2016) proved that liquidity does not affect dividend policy. Companies with a high level of liquidity will indirectly provide an idea that the company can meet its short-term obligations. The development of the dividend distribution of companies listed on the Indonesia Stock Exchange from 2010-2019 is shown as follows:

Figure 1.

Development of dividend distribution companies in Indonesia 2010-2019

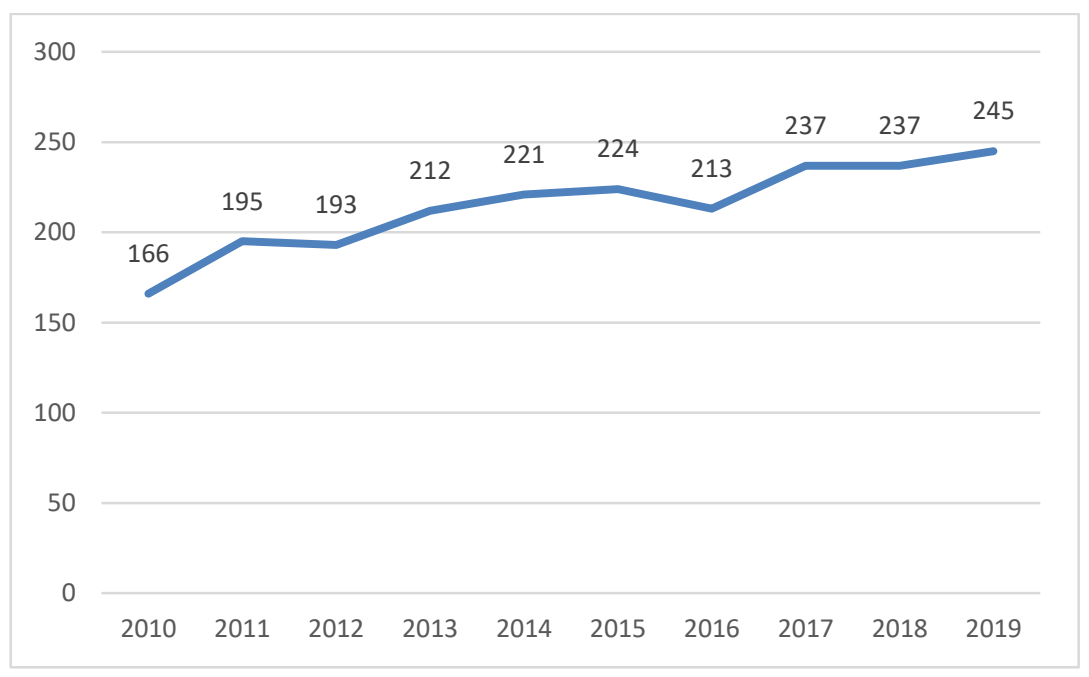

Source: Idx.co.id

Based on the picture above, it can be seen that companies that have distributed cash dividends from the last ten years tend to increase. The phenomenon of cash dividend distribution is not only caused by the profit growth factor. One example of a company that has consistently distributed dividends in the last ten years is P.T. Media Nusantara Citra, Tbk. From the released financial reports, it can be seen that the company's 2019 
net profit has increased by 46.52 percent compared to 2018 , the profitability and liquidity ratio has also increased, but this year at the general meeting of shareholders decided not to distribute dividends because they chose to strengthen the capital structure.

From the research results as well as the phenomena found above, it is still found that there are differences in the results of research from previous researchers. This motivates researchers to re-examine the effect of debt policy, profitability, managerial ownership structure, and liquidity on dividend policy.

\section{Theoretical Framework and Hypothesis Development}

\subsection{Theoretical Framework}

\subsubsection{Agency Theory}

Agency Theory explains agency relationships and the problems they cause (Jensen and Meckling, 1976). Agency theory explains the relationship between agent and principal. The agent is the management of the company, while the principal is the owner (shareholder). Agency theory describes the separation of company property rights and responsibility for decision making (Jensen and Meckling, 1976).

\subsubsection{Signaling Theory}

Spence first introduced the signaling theory in his research entitled Job Market Signaling. Spence (1973) argues that a signal gives a signal, the sender (the owner of the information) tries to provide pieces of relevant information that can be used by the recipient. The receiving party will then adjust its behavior according to its understanding of the signal. Signaling theory suggests how a company should provide signals to users of financial reports. This signal is in the form of information about what management has done to realize the owner's wishes.

\subsubsection{Dividend Policy}

Dividend policy is one of the policies in the company that must be carefully considered and considered. Dividend policy determines the amount of profit that can be distributed to shareholders (dividends) and the allocation of profit that can be retained 
by the company. The greater the retained profit, the smaller the profit distributed to shareholders (Firmanda et al., 2015).

\subsubsection{Debt Policy}

Liabilities as an alternative cost, which is a source of funding from outside the company. The debt policy is closely related to financing for the implementation of corporate planning that will be developed. Company debt policy is an act of company management that will fund the company using capital that comes from debt. Brigham and Houston (2011: 78) debt policy is a policy regarding companies' decisions to carry out their operations using financial debt or financial leverage.

\subsubsection{Profitability}

Profitability is the company's ability to earn a profit, which influences dividend policy. Suppose the company has a high level of profitability. In that case, the profits it will get will also be high, and in the end, the profits available for distribution to shareholders will be even greater. The greater the profit available to shareholders, the greater the dividend payment to shareholders or the allocation for retained earnings. Profitability is the main factor for companies in distributing dividends to shareholders, so that profitability is the most crucial final factor for dividends (Rais and Santoso, 2017). According to Hanafi and Halim (2016), the profitability ratio is very beneficial for the company's continuity because it can help companies find out the contribution of company profits in the short or long term. Therefore, dividends are taken from the company's net profit so that these profits will affect the amount of dividends paid. The greater the profits, the greater the company's ability to pay dividends.

\subsubsection{Managerial Ownership Structure}

Managerial ownership is ownership where there is involvement between shareholders, namely the commissioners and directors who play an active role in making decisions to get equality with other shareholders. Managerial ownership aims to supervise and monitor the manager's behavior, which is one aspect of corporate 
governance that can minimize supervisory costs or what is called agency cost (Rais and Santoso, 2017).

\subsubsection{Liquidity}

Liquidity is the company's ability to pay off its short-term liabilities. The company's liquidity position directly affects the company's ability to pay dividends. Liquidity is very basic for a company, the liquidity of a company will be reflected in its daily routine, which can be considered through payment to creditors on time or payment of salaries on time, because it can be seen that liquidity is the ability to pay off shortterm liabilities or current debts that will be repaid in within one year (Bawamenewi and Afriyeni, 2019).

\subsection{Hypothesis Development}

\subsubsection{Effect of Debt Policy on Dividend Policy}

The debt policy is an external funding decision because it is carried out to increase company funds, which will be used to meet the company's operational needs. Companies with a high level of debt will bear the risk of large losses when economic conditions deteriorate, and when economic conditions improve, companies will earn large profits (Brigham, 2011: 160). In agency theory, it explains that if the debt is too high, it will decrease dividends where most of the profits will be allocated as reserves for debt repayment. The results of research conducted by Thaib (2015) and Banselang (2014) prove that debt policy affects dividend policy. Thus, the following hypothesis is proposed:

\section{H1: Debt policy affects dividend policy}

\subsubsection{Effect of Profitability on Dividend Policy}

Profitability is the company's ability to generate profits (profitability) at the level of sales, assets, and share capital. The profits obtained by the company can affect the level of dividends that will be distributed to shareholders. The higher the company's profit, the higher the dividends that will be distributed to shareholders (Isticharoh, 2016). In the signaling theory, it explains that companies announce profits to give 
signals to investors about the company's success in posting profits and prospects; the company will only increase dividend payments when profits increase; in other words, the greater the profit obtained, the greater the company's ability to pay dividends. Research conducted by Nugroho (2004), Suharli (2008), Pribadi and Sampurno (2012), Sunarya (2013), and Halviani and Sisdyani (2014), Bansaleng (2014), Thaib (2015), and Yudiana (2016) prove that profitability affects dividend policy. Thus, the following hypothesis is proposed:

\section{H2: Profitability affects dividend policy}

\subsubsection{The Effect of Managerial Ownership Structure on Dividend Policy}

Managers have the same opportunity to be involved in share ownership in order to equalize with shareholders. Shareholders who have positions in company management both as creditors and as the board of commissioners are referred to as managerial ownership (Wijayanto and Putri, 2018). Most companies owned by management will tend to pay low dividends because managers have expectations of future investments funded internally. However, if managerial ownership is low, the company will pay high dividends to give a good impression of future performance to improve its reputation in front of shareholders (Isticharoh, 2016). In agency theory, it explains that management acts as an agent to manage the company well, while shareholders act as principals to control the company's performance. This dividend distribution policy is the duty of management to manage the company well so that the company can maximize profits and pay dividends to shareholders. The results of research conducted by and Fadah dan Novi (2008), Affifah (2018), Isticharoh (2016), and Indriani (2016) prove that managerial ownership structure affects dividend policy. Thus, the following hypothesis is proposed:

H3: Managerial ownership structure affects dividend policy

\subsubsection{The Effect of Liquidity on Dividend Policy}

A company's liquidity shows the company's ability to fund the company's operations and pay off its short-term obligations. Therefore, companies with adequate liquidity have a better chance of paying dividends (Arilaha, 2009). Dividends will be 
more paid if the level of company liquidity is higher because dividends are cash outflows. Companies with high profits do not necessarily own sufficient cash, so if the company wants to distribute dividends, the company needs to have sufficient cash because dividends are generally distributed in the form of cash dividends (Devi and Surdhika, 2014). The signaling theory explains that the company's high liquidity value is a signal or a signal for investors that the company is in good condition or level of liquidity so that it will be able to fulfill its obligations to pay dividends. Research conducted by Sumiadji (2011), Dewi and Wirajaya (2013), Ahmed (2015), and Monika (2018) proved that liquidity affects dividend policy. Thus, the following hypothesis is proposed:

\section{H4: Liquidity affects dividend policy}

\section{Research Method}

Researchers used the documentation method by searching for secondary data. Documentation is carried out by collecting data from financial reports that support and complement the data from 2014 to 2018 . The next stage is collecting company data in financial reports on the Indonesia Stock Exchange (IDX) website (www.idx.go.id). The analysis used is analysis multiple linear; the dependent variable used is dividend policy. While the independent variables used are debt policy, managerial ownership structure, profitability, and debt policy.

The indicators used in measuring dividend policy are the Dividend Payout Ratio (DPR), which is calculated using the formula (Bawamenewi, 2019):

$$
D P R=\frac{\text { Dividend per share }}{\text { earnings per share }} \times 100 \%
$$

The indicator used in measuring debt policy is the Debt to Equity Ratio (DER), namely the formula (Bawamenewi, 2019):

$$
D E R=\frac{\text { Total Debt }}{\text { Total Equity }} \times 100 \%
$$


The indicator used in measuring the profitability of Return On Equity (ROE) is the formula (Bawamenewi, 2019):

$$
R O E=\frac{\text { Earning Before Tax }}{\text { Total Equity }} \times 100 \%
$$

The indicators used in measuring managerial ownership structure with the formula (Sumanti and Mangantar, 2015):

$$
M O=\frac{\text { number of managerial shares }}{\text { number of shares outstanding }} \times 100 \%
$$

The indicators used in measuring the current liquidity ratio (C.R.) are the formula (Bawamenewi, 2019):

$$
C R=\frac{\text { Current Asset }}{\text { Current Liabilities }} \times 100 \%
$$

The population used in this study are all manufacturing companies listed on the Indonesia Stock Exchange (BEI). In this research, the sample determination is used in manufacturing companies listed on the Indonesia Stock Exchange (BEI) 2014-2018. The study's sampling technique used a non-probability sampling method with a purposive sampling technique, namely a sampling technique with specific considerations and objectives, while the sample criteria were manufacturing companies listed on the Indonesia Stock Exchange (IDX) during 2014-2018. Companies that published complete financial reports during 2014-2018 companies that used the rupiah's unit value in their financial statements, manufacturing companies that experienced profits during 2014-2018, companies that distributed dividends consecutively during the 2014-2018 period, companies that provided all the required data regarding the research variables.

This study uses a descriptive analysis to describe the research variables. The descriptive statistics used are the average, minimum and maximum values. Simultaneously, multiple linear regression analyses and in this study were used to test the research hypothesis. Hypothesis testing is carried out through several stages, namely 
the classical assumption test, simultaneous significance test, $t$ statistical test, and the determination test coefficient.

$$
\mathrm{Y}=\alpha+\beta 1 \mathrm{X} 1+\beta 2 \times 2+\beta 3 \times 3+\beta 4 \times 4+\varepsilon
$$

Information :

$$
\begin{array}{ll}
\mathrm{Y} & =\text { Dividend Policy } \\
\mathrm{a} & =\text { Constant } \\
\beta & =\text { Regression Coefficient } \\
\mathrm{X} 1 & =\text { Debt Policy } \\
\mathrm{X} 2 & =\text { Managerial Ownership Structure } \\
\mathrm{X} 3 & =\text { Profitability } \\
\mathrm{X} 4 & =\text { Liquidity } \\
\varepsilon & =\text { Error }
\end{array}
$$

\section{Results of Research and Discussion}

The analysis used in this study includes an overview of the object of the study, descriptive statistics, data analysis requirements test, and hypothesis testing. The data collected is secondary data in the form of company financial reports. Based on the sampling criteria previously stated, 60 company samples were obtained.

\subsection{Descriptive Statistical Analysis Results}

Table 1.

Descriptive statistics

\begin{tabular}{cccccc}
\hline Variable & $\mathrm{N}$ & Minimum & Maximum & Mean & $\begin{array}{c}\text { Std. } \\
\text { Daviation }\end{array}$ \\
\hline X1 & 60 & 0,12 & 1,82 & 0,6115 & 0,39543 \\
X2 & 60 & 0,02 & 0,37 & 0,1395 & 0,07914 \\
X3 & 60 & 0.01 & 0,26 & 0,036 & 0,06543 \\
X4 & 60 & 1,07 & 15,16 & 3,375 & 3,00932 \\
Y & 60 & 0,07 & 1,90 & 0,3896 & 0,26063 \\
$\begin{array}{l}\text { Valid } \\
\text { (listwise) }\end{array}$ & 60 & & & & \\
\hline
\end{tabular}

Source: Secondary data, 2020. 
A descriptive statistic describes the character of the sample in this study. The results of descriptive statistical testing are presented in table 1. Based on the results of statistical tests in Table 1 above, it can be explained that descriptive statistics for dividend policy (DPR) obtained the lowest value ( $\min$ ) of 0.07 and the highest (max) of 1.90 with an average (mean) dividend policy of 0.3896 and a standard deviation of 0.26063. Descriptive statistics for debt policy (DER) obtained the lowest (min) 0.12 and the highest $(\max ) 1.82$ with an average (mean) debt policy of 0.6115 and a standard deviation of 0.39543. Descriptive statistics for profitability (ROE) obtained the lowest result (min) 0.02 and the highest $(\max ) 0.37$ with an average (mean) profitability of 0.1395 and a standard deviation of 0.07914. Descriptive statistics for managerial ownership (MO) obtained the lowest (min) 0.00 and the highest (max) 0.26 results with an average (mean) managerial ownership of 0.0360 and a standard deviation of 0.06543 . Further, descriptive statistics for liquidity (C.R.) obtained the lowest results (min) 1.07, and the highest (max) was 15.16 with an average (mean) liquidity of 3.3750 and a standard deviation of 3.00932 .

\subsection{Multiple Linear Regression Test Results}

Based on the test results using multiple linear regression analysis, the results are described as follows:

Table 2.

Multiple Linear Regression Analysis Test Results

\begin{tabular}{lcccc}
\hline Variable & \multicolumn{2}{c}{$\begin{array}{c}\text { Regression Coeficient } \\
\text { (B) }\end{array}$} & Sig & Information \\
& & $-0,353$ & 0,266 & H1 rejected \\
Debt Policy & & 0,288 & 0,037 & H2 accepted \\
Profitability & & $-0,150$ & 0,667 & H3 rejected \\
Manajerial Ownership & & $-0,029$ & 0,309 & H4 rejected \\
Liquidity & $=-0,783$ & & & \\
Constant & $=0,074$ & & \\
Adjusted R square & $=0,370$ & & \\
R & $=0,137$ & & \\
R Square & $=0,083$ & & \\
Sig. F & & & \\
Source: Secondary data, 2020. & & & \\
\end{tabular}

Source: Secondary data, 2020. 
Based on the results of multiple linear regression calculations using the SPSS 26.0 program, the results of the study are explained as follows:

\section{Effect of Debt Policy on Dividend Policy}

The hypothesis testing results show that debt policy statistically does not affect dividend policy, so hypothesis 1 is rejected. This shows that the size of a company's debt policy will not affect the dividends' size that will be distributed by the company. These results indicate that even though the company's debt is high or low, the company will try to maintain the distribution of dividends to shareholders so that the company is considered to have good prospects in the future to continue to invest (Setiawati and Yesisca, 2015). Also, the high amount of debt does not prevent the company from distributing dividends because the company will also pay attention to investors who expect dividends, so the debt to equity ratio does not affect dividend policy. These results support the research conducted by Ekawati and Bambang (2015) and Affifah (2018), and with the results of research, debt policy does not affect dividend policy.

\section{Effect of Profitability on Dividend Policy}

Based on the hypothesis testing results, the statistical results of profitability affect dividend policy, so hypothesis 2 is accepted. This shows that the size of a company's profitability will affect the size of the dividends to be distributed. The effect of profitability on dividend policy is that companies that can generate higher profits indicate that the company's performance is high to share company profits in the form of dividends (Wijayanti, 2016). The higher the company's net profit, the greater the dividends that will be distributed to shareholders. These results support research conducted by Banselang (2014), Thaib and Taroreh (2015), and Yudiana (2016), with research results showing that profitability affects dividend policy.

\section{The Effect of Managerial Ownership Structure on Dividend Policy}

The results of hypothesis testing show that the statistical results of managerial ownership structure do not affect dividend policy. So that hypothesis 3 is rejected. This 
shows that the size of the managerial ownership of a company will not affect the size of the dividends that will be distributed by the company; besides that in the clientele effect theory, it explains that in the end, management who only has a small amount of share ownership will get a low dividend payout ratio. Alternatively, they even prefer obtaining capital gains. The reason that managerial ownership does not affect dividend policy is the relatively small percentage of managerial ownership in a company, thus indicating that the managerial party has a role as a shareholder with a minority of shares. This relatively small amount makes managerial parties focus only on managers in the company. They do not place too much importance on dividend distribution generated by the company but focus on capital gains. This is reinforced by Wijayanto (2018), who says managerial ownership does not influence dividend policy because managers' percentage of managerial ownership is less compared to other shareholders. Managers do not have great power in determining dividend policy, so it can be said that managerial ownership does not affect dividend policy. These results support research conducted by Banselang (2014), Rais and Santoso (2014), which state that managerial ownership does not affect dividend policy.

\section{The Effect of Liquidity on Dividend Policy}

Based on the results of hypothesis testing, it shows that the results of the liquidity statistics do not affect dividend policy. So that hypothesis 4 is rejected. This shows that the size of a company's liquidity will not affect the size of the dividends that will be distributed by the company. According to Ginting (2018), liquidity is the company's ability to fund its operations and pay off its short-term obligations. Therefore, companies that have adequate liquidity have a better chance of paying dividends. Liquidity is said not to affect dividend policy because liquidity is not the primary determinant for the company in distributing dividends; when the company can fulfill its short-term obligations, it is not sure that the company will distribute dividends to shareholders or investors because there are things that need to be considered both internal companies such as for finance the company's operational activities and external companies such as for investment opportunities. These results support research 
conducted by Bawamenewi (2019) and Rostanty (2017), which states that liquidity does not affect dividend policy.

\section{Conclusion and Limitation}

\subsection{Conclusion}

Based on the research results, it can be concluded as follows: Firstly, debt policy does not affect dividend policy. This shows that the size of the debt policy will not affect the size of the dividend distribution. The company will continue to distribute dividends to shareholders so that the company is considered to have good prospects in the future to continue to invest. Secondly, profitability affects dividend policy. This shows that the size of the profitability will affect the size of the dividend distribution. If the company earns high profits, the distribution of dividends to shareholders will also increase. Thirdly, managerial ownership does not affect dividend policy. This shows that the size of managerial ownership will not affect the size of the dividend distribution. Because the percentage of managerial ownership owned by managers is less than other shareholders, managers do not have great power in determining dividend policy. Finally, liquidity does not affect dividend policy. This shows that the size of the liquidity will not affect the size of the dividend distribution. Because the company will continue to distribute dividends to shareholders using reserve profits.

\subsection{Limitation}

This study has some limitations that need to be addressed for future study. First, to increase research time to expand observations so that the results obtained can be generalized. Second, for further research, it is expected to add other variables that are considered to influence dividend policy, such as the investment opportunity set, institutional ownership, free cash flow, and other variables. 


\section{Reference}

Ahmed, I. E. 2015. Liquidity, profitability, and the dividends payout policy. World Review of Business Research 5 (2): 73-85.

Bhattacharya, S. 1979. Imperfect information, dividend policy, and the bird in the hand fallacy. Rand Journal of Economics 10: 259-270.

Bawamenewi, Afriyeni. 2019. Pengaruh Profitabilitas, Leverage, Dan Likuiditas Terhadap Kebijakan Dividen Pada Perusahaan Manufaktur Yang Terdaftar Di Bursa Efek Indonesia. Jurnal Pundi, Vol. 03, No. 01, Maret 2019.

Brigham, E.F dan Joel Houston. 2011. Dasar-dasar Manajemen Keuangan Terjemahan. Edisi 10. Salemba Empat, Jakarta.

Clarensia, Sri Rahayu., dan Nur Azizah. 2017. Pengaruh Likuiditas, Profitabilitas, Pertumbuhan Penjualan, dan Kebijakan Dividen terhadap Harga Saham (Studi Empirik pada Perusahaan Manufaktur yang Terdaftar di Bursa Efek Indonesia Tahun 2007-2010). Jurnal Bisnis dan Akuntansi,Hal 72-88.

Dewi, A. S. M., dan A. Wirajaya. 2013. Pengaruh struktur modal, profitabilitas dan ukuran perusahaan pada nilai perusahaan. Jurnal Akuntansi Universitas Udayana 4 (2): 358 372. https://doi.org/ISSN : 2302-8556

Ekawati, Gresylia., dan Bambang Banu Siswoyo, 2015. The Effects of Current Ratio and Debt to Equity Ratio on Dividend Policy through Net Profit Margin (A Study on Manufacturing Companies Listed in Indonesia Stock Exchange in the Period of 2013). Research Journal of Finance and Accounting from IISTE. ISSN 2222-1697 (Paper) ISSN 2222-2847 (Online). Vol.6, No.24, 2015

Fadah dan Novi. 2008. Interdependensi Kebijakan Dividen, Kebijakan Hutang dan Kepemilikan Manajerial: Perspektif Teori Keagenan. National Conference on Management Research.

Firmanda, Kharis Raharjo., dan Abrar Oemar. 2015. Pengaruh Kepemilikan Manajerial, Kepemilikan Institusional, Kebijakan Hutang, Profitabilitas, Ukuran Perusahaan Dan Cash Position Terhadap Kebijakan Deviden. Jurnal Ekonomi\& Bisnis, hal 34-50.

Halviani, M. D., dan E. A. Sisdyani. 2014. Pengaruh moderasi good corporate governance pada return on asset dan dividend payout ratio. Jurnal Akuntansi Universitas Udayana 7 (2): 591-607.

Hanafi, Mamduh M dan Abdul Halim. 2016. Analisis Laporan Keuangan. Edisi. Kelima. Yogyakarta: UPP STIM YKPN

Harris, M. dan Raviv, A. 1990. Capital Structure And The Informational Role Of Debt. Journal of Finance 45: 321-349. 
Hartono, J. 2000. An Agency-Cost Explanation for Divident Payments. Working Paper. Gadjah Mada University. Yogyakarta.

Hashim, Sahaida Laily Binti Md. 2017. Analysis On Dividend Payout: Empirical Evidence Of Property Companies In Malaysia. International Journal of Industrial Management (IJIM). ISSN (Print): 2289-9286; e-ISSN: 0127-564x; Volume 3, June 2017. Universiti Malaysia Pahang, Malaysia.

Hatta, A.J. 2002. Faktor-Faktor yang Mempengaruhi Kebijakan Dividen:Investigasi Pengaruh Teori Stakeholder. Jurnal Akuntansi \& Auditing Indonesia, Desember, 6 (2).

Hermuningsih, Sri. 2007. Analisis Faktor-faktor yang mempengaruhi Dividend Payout Ratio pada perusahaan yang Go Public di Indonesia. Jurnal Ekonomi \& Pendidikan, Volume 4 Nomor 2, November 2007. Hal 47-62.

Jensen, M. C. 1986. Agency costs of free cash flow, corporate finance, and takeovers. American Economic Review 76: 323-339.

Jensen, M.C., dan Meckling, W.H. 1976. Theory of the Firm: Managerial behavior. Agency cost and Ownership Structure. Journal of Financial Economics 305-360.

Jiang, Fuxiu., Yunbiao Ma., and Beibei Shi. 2016. Stock Liquidity and Dividend Payouts. Journal of Corporate Finance (2016), doi:10.1016/j.jcorpfin.2016.12.005:

Miguel, A., Pindado, J. dan de la Torne, C. 2005. How do entrenchment and expropriation phenomena affect control mechanisms?. Corporate Governance: An International Review 13(4): 1-29.

Nugroho, S. 2004. Analisis faktor - faktor yang mempengaruhi kebijakan dividen pada perusahaan yang terdaftar di BEI. Universitas Diponegoro. http://eprints.undip.ac.id/10181/.

Nurchaqiqi, Rozi., and Trisni Suryarini. 2018. The Effect of Leverage and Liquidity on Cash Dividend Policy with Profitability as Moderator Moderating. Accounting Analysis Journal 7(1). DOI 10.15294/aaj.v5i3.18631. p-ISSN 2252-6765

Nuringsih, Kartika. 2005. Analisis Pengaruh Kepemilikan Manajerial, Kebijakan Hutang, ROA dan Ukuran Perusahaan terhadap Kebijakan Dividen: Studi 1995-1996. Jurnal Akuntansi dan Keuangan Indonesia, Vol. 2, No. 2, Juli-Desember 2005, pp 103-123.

Pribadi, A. S., dan R. D. Sampurno. 2012. Analisis pengaruh cash position, firm size, growth opprtunity, ownership, dan return on asset terhadap dividend payout ratio. Diponegoro Journal of Management 1 (4): 201-211.

Rais, dan Hendra F. Santoso. 2017. Pengaruh Kepemilikan Manajerial, Kepemilikan Institusional, Profitabilitas Dan Ukuran Perusahaan Terhadap Kebijakan Deviden. Jurnal Ilmiah Manajemen Bisnis, Vol. 17, No. 2, Juli - Desember 2017. Hal 111-123. 
Rozeff, M. 1982. Growth, beta, and agency costs as determinants of dividend payout ratios. Journal of Financial Research 3: 249-259.

Shleifer, A. dan R. Vishny. 1986. Large shareholders and corporate control. Journal of Political Economy 94: 461-488.

Siegel, J.G. dan Shim, J.K. 1999. Kamus Istilah Akuntansi (terjemahan). Cetakan Ke 3. Jakarta: PT. Elex Media Komputindo.

Sindhu, Muzammal Ilyas., Shujahat Haider Hashmi \& Ehtasham Ul Haq.2016. Impact of ownership structure on dividend payout in Pakistani non-financial sector, Journal Cogent Business \& Management, 3:1, 1272815

Singh, M. dan Davidson III, W. N. 2003. Agency cost, ownership structure, and corporate governance mechanisms. Journal of Banking dan Finance 27: 793-816.

Suharli, M. 2008. Pengaruh profitability dan investment oppurtunity set terhadap kebijakan dividen tunai dengan likuiditas sebagai variabel penguat. Jurnal Akuntansi dan Keuangan 9 (1): 9-17. https://doi.org/10.9744/jak.9.1.pp. 9-17

Sumiadji. 2011. Analisis variabel keuangan yang mempengaruhi kebijakan deviden. Jurnal Dinamika Akuntansi 3 (2). https://doi.org/10.15294/jda.v3i2.1952.

Sunarya, D. H. 2013. Pengaruh kebijakan utang, profitabilitas dan likuiditas terhadap kebijakan dividen dengan size sebagai variabel moderasi pada sektor manufaktur periode 2008 2011. Jurnal Ilmiah Mahasiswa Universitas Surabaya 2 (1): 1-19.

Wijayanto, dan Anggi Navulani Putri. 2018. Analisis Pengaruh Rasio Likuiditas, Rasio Leverage , Rasio Profitabilitas Dan Kepemilikan Manajerial Terhadap Kebijakan Dividen. Jurnal Aktual Akuntansi Keuangan Bisnis Terapan ISSN : 2622-6529, Vol. 1, No 2, November 2018. Hal 105-118.

Yudistra, Fitrian Achmad., Didik Tandika., dan Azib. 2016. Pengaruh Likuiditas, Dan Profitabilitas Terhadap Kebijakan Dividen (Studi Kasus Perusahaan Yang Tergabung Dalam Indeks LQ45 di BEI Periode 2012-2015). Journal Prosiding Manajemen. ISSN:2460-6545. 